\title{
Course for the qualification of nurses in the care of children with genetic diseases: an experience report
}

\author{
Curso para qualificação de enfermeiros no cuidado de crianças \\ com doenças genéticas: relato de experiência \\ Curso de calificación de enfermeras en el cuidado de niños con \\ enfermedades genéticas: informe de experiencia
}

\section{How to cite this article:}

Herber S, Rodrigues FA, Vaccari A. Course for the qualification of nurses in the care of children with genetic diseases: an experience report. Rev Gaúcha Enferm. 2021;42(spe):e20200193. doi: https://doi.org/10.1590/19831447.2021.20200193

\footnotetext{
a Hospital de Clínicas de Porto Alegre (HCPA). Porto Alegre, Rio Grande do Sul, Brasil.

- Secretaria Estadual do Rio Grande do Sul (SES/RS). Porto Alegre, Rio Grande do Sul, Brasil.

' Universidade Federal do Rio Grande do Sul (UFRGS), Escola de Enfermagem, Departamento de Enfermagem Materno-infantil. Porto Alegre, Rio Grande do Sul, Brasil.
}

\section{Silvani Herber ${ }^{a}$ \\ Fernanda Araújo Rodrigues ${ }^{\mathrm{b}}$ Alessandra Vaccaric}

\section{ABSTRACT}

Objective: To describe the experience of developing and operating an extension course to qualify nurses in the care of children with genetic diseases.

Method: An experience report about the conduction of a university extension course with eight participants, developed at a public university in southern Brazil. It was a face-to-face course in November 2019.

Results: The course covered the following themes: introduction to Genetics in Nursing; rare diseases; inborn errors of metabolism; Neonatal Screening Program; and microcephaly. The content was developed through theoretical aspects, presentation of clinical cases, practical activities, and realistic simulation.

Conclusion: The extension course provided knowledge to nurses, who develop their functions as team leaders, enabling professional development and the promotion of information on the topic, which corroborates the objectives of the Nursing Now campaign.

Keywords: Genetic diseases, inborn. Pediatrics. Education, Nursing. High fidelity simulation training.

\section{RESUMO}

Objetivo: Descrever a experiência de desenvolvimento e operacionalização de um curso de extensão para qualificar enfermeiros no cuidado de crianças com doenças genéticas.

Método: Relato de experiência sobre a realização de um curso de extensão universitária com oito participantes, desenvolvido em uma universidade pública no sul do Brasil. 0 curso foi realizado na modalidade presencial, em novembro de 2019.

Resultados: 0 curso contemplou os seguintes temas: introdução à genética na enfermagem, doenças raras, erros inatos do metabolismo, Programa de Triagem Neonatal e microcefalia. 0 conteúdo foi desenvolvido por meio do desenvolvimento dos aspectos teóricos, apresentação de casos clínicos, atividades práticas e simulação realística.

Conclusão: 0 curso de extensão proporcionou conhecimento aos enfermeiros, que desenvolvem suas funções como líderes de equipe, permitindo o desenvolvimento profissional e a disseminação de informações sobre o tema, o que corrobora os objetivos da campanha Nursing Now.

Palavras-chave: Doenças genéticas inatas. Pediatria. Educação em enfermagem. Treinamento com simulação de alta fidelidade.

\section{RESUMEN}

Objetivo: Describir la experiencia de desarrollo y operacionalización de un curso de extensión para calificar enfermeras en el cuidado de niños con enfermedades genéticas.

Método: Informe de experiencia sobre la realización de un curso de extensión universitaria con ocho participantes, desarrollado en una universidad pública en el sur de Brasil. El curso tuvo lugar en persona, en noviembre de 2019.

Resultados: El curso cubrió los siguientes temas: introducción a la Genética en Enfermería; enfermedades poco comunes; errores innatos del metabolismo; Programa de detección neonatal; y microcefalia. El contenido se desarrolló mediante el desarrollo de aspectos teóricos, la presentación de casos clínicos, actividades prácticas y simulación realista.

Conclusión: El curso de extensión proporcionó conocimiento a las enfermeras, quienes desarrollan sus roles como líderes de equipo, permitiendo el desarrollo profesional y la difusión de información sobre el tema, lo que corrobora los objetivos de la campaña Nursing Now.

Palabras clave: Enfermedades genéticas congénitas. Pediatría. Educación en Enfermería. Enseñanza mediante simulación de alta fidelidad. 


\section{口INTRODUCTION}

The diagnosis and treatment of genetic diseases improved in the last years for being a concern of the Ministry of Health (Ministério da Saúde, MS). In this regard, the National Policy on Comprehensive Care for People with Rare Diseases (RDs) was published in 2014 and resources were instituted to afford the referral services in the Unified Health System ${ }^{(1)}$. In this policy, nurses play an essential role as their participation in assistance teams is required for enabling and implementing the referral services.

A disease is classified as rare when it affects up to 65 out of 100,000 individuals and, despite this classification, there are between 6,000 and 8,000 different RDs around the world, $80 \%$ being caused by genetic factors ${ }^{(1)}$, which generate a considerably significant epidemiological impact when gathered in a category ${ }^{(2)}$.

This policy aims at reducing the mortality and inability caused by RDs, which are classified according to their nature: of genetic or non-genetic origin. In the first axis of the policy, focus of this publication, the following genetic conditions are included: congenital anomalies and Inborn Errors of Metabolism (IEMs) ${ }^{(1)}$.

In Brazil, 2\% to 3\% of the total live births have some congenital anomaly, also including children with late onsets. This figure can reach 5\%, being the second cause of infant mortality and responsible for more than $1 / 3$ of pediatric hospitalizations ${ }^{(1)}$. In the case of the IEMs,3,000 new cases are estimated every year in Brazil, and the worldwide incidence of their category is estimated at 1:1,000 to 1:2,500 births $s^{(1)}$.

IEMs form a group with 550 diseases that are generally multi-systemic, many of them evolving with some neurological impairment and early death, causing the need of specialized follow-up for these children ${ }^{(1)}$. In this group, Maple Syrup Urine Disease (MSUD) and Mucopolysaccharidosis are found: two genetic diseases that advanced in their diagnosis and treatment in the last years; however, there is no data about their prevalence in Brazil.

Another relevant event in the area took place in 2015 when the World Health Organization declared the outbreak of the Zika Virus (ZIKV) infection and its possible association with cases of congenital microcephaly as a Public Health Emergency Of International Concern in Latin America ${ }^{(3)}$. Therefore, due to the need for studies, the MS established the mandatory notification of newborns (NBs) with microcephaly ${ }^{(4)}$.

Consequently, as it is a new infection, detected only in 2015, as well as the implementation of a new policy in 2014, it was necessary to train nurses to take care of patients with congenital anomaly caused by ZIKV and IEMs. This training corroborates one of the goals of the Nursing Now campaign, which aims at empowering nurses to help them face the current health challenges ${ }^{(5)}$.

It is also known that the continuing education of nurses improves daily clinical care, as well as ethical, legal, and psychological issues involving genetic diseases, contributing to the assistance provided to the patients ${ }^{(6)}$. Therefore, nurses that acquire more knowledge about the theme have more conditions to support the well-being of patients and their family members, at the same time that they promote new knowledge $e^{(7)}$.

Currently, the literature on the approach of genetic diseases by nurses is still scarce. Therefore, the relevance of this study lies in the fact that it shares the qualification strategy of these professionals based on the knowledge and work developed by a referral service in the treatment of genetic diseases. In view of that, the objective of this study is to describe the experience of developing and operating an extension course to qualify nurses in the care of children with genetic diseases.

\section{METHOD}

This is an experience report about the experience of developing and operating a university extension course about Nursing care in children with genetic diseases carried out in the Nursing School of the Federal University of Rio Grande do Sul (Universidade Federal do Rio Grande do Sul, UFRGS). It was a face-to-face course lasting 20 hours and carried out in November 2019, with a population consisting of eight nurses who work or are interested in the neonate, pediatric, or medical genetic areas. The course was announced on social media (Facebook ${ }^{\circ}$ and Instagram ${ }^{\circ}$ ) and by email to the nurses working in the Clinical Hospital of Porto Alegre (Hospital de Clínicas of Porto Alegre, HCPA) a month before its start. Enrollments were done through electronic forms (Google Forms') and the organization team was composed of three nurses with training and assistance experience in neonatal, pediatric, and medical genetic Nursing. The course contents were added due to the inclusion of these diseases in the MS protocols and considering the experience of the organizers.

This report meets one of the goals of the Nursing Now goals, which aims at empowering Nursing professionals as health protagonists. The objectives of this course were as follows: to qualify the training of leading nurses and multipliers of knowledge about the assistance to people with genetic diseases; to instruct nurses to develop a care plan adequate for these patients; and to provide a field of learning and exchange of experiences. Therefore, this course focused on the knowledge with greater applicability in the nurses' 
actions in their care practice, developing the abilities of this professional in the care of children with genetic diseases.

The preparation of the extension course followed these stages: a meeting to list the contents, submission to the Dean of Extension Office (Pró-reitoria de Extensão, PROREXT), bibliographic review to prepare classes and clinical cases, and request for the authorization from the HCPA for the participants to follow the outpatient clinic activities. In addition to that, a scenario for realistic simulation was constructed based on the professional experiences of the organization team and a pilot test was performed, respecting all indications of the International Nursing Association for Clinical Simulation and Learning $(\text { INACSL })^{(8)}$ for good practices in realistic simulation. The pilot test consists of previously examining the clinical case described and all the necessary items, reducing or eliminating unexpected events during the simulation.

The extension action, course modality, "Genetics in Pediatrics: Applications for Nursing" was approved by the PROREXT under number 41805. After its conclusion, a final report with data related to the course was issued and approved, keeping the participants' anonymity.

In addition to this, any information that could identify the patients in the presentation of the clinical cases was kept confidential. In the HCPA outpatient clinic, an authorization was requested from the parents to monitor medical appointments and/or the infusion of enzyme replacement therapy; no data of these observations was collected. All the biosafety measures were also followed.

\section{RESULTS}

Among the participating nurses, four belong to a Neonatal Intensive Care Unit (NICU) team, one works in a Pediatric Cancer Treatment Unit, one in the surgical center, one in a Basic Health Unit (BHU), and one develops their resident's activities in an NICU. The training time ranged from three months to 15 years. Regarding the titles, three completed master's degree and two, specialization courses. In relation to the main reason of interest in the course, all the participants asserted the scarce approach on the theme during their training and the follow-up of cases of children with suspicion or diagnosis of these pathologies in their daily practices.

The course was divided into five stages. The first consisted of the theoretical approach on the following themes: Introduction to Genetics in Nursing, rare diseases, IEMs (such as MSUD and mucopolysaccharidosis), Program of Neonate Screening, and microcephaly. In this stage, the contents were worked on in lectures and collaborative classes, delivered by nurses and nutritionists that work with children with genetic diseases.

In the second stage of the course, the participants discussed two clinical cases, described in Chart 1.

In the third stage, two practical activities were conducted so that the participants could experience the subjects approached: infusions of patients with mucopolysaccharidosis and Nursing appointments in the IEM outpatient clinic. The participants observed the clinical characteristics of these patients and the Nursing demands during follow-up. The relevance of this stage is emphasized, as the HCPA is qualified as a referral service for $\mathrm{RDs}$ of genetic origin.

The fourth stage was a realistic simulation carried out in the Laboratory of Nursing Practices of the Nursing School at the UFRGS, in which it was possible to discuss, in the debriefing, the themes approached throughout the course. In the simulation, all the stages recommended by the INACSL ${ }^{(8)}$ were respected, namely: briefing, running, and debriefing.

For this stage, the "Nursing Appointment about Microcephaly in a BHU" scenario was constructed. The following objectives were listed to develop learning during the simulation: to value effective communication and the relationships between nurse and family and between the assistant and the mother, with correct guidelines in the management of conflicts with the child's father. The realistic simulation stages are described in Chart 2.

\section{Second Stage - Discussion of Clinical Cases}

Case 1: Child, two years old, with microcephaly caused by ZIKV. For this situation, gestational, birth, and clinical data were analyzed. The Nursing care actions throughout the follow-up of this child were also verified, from prenatal to childcare.
Case 2: Child, one year old, with early MSUD diagnosis at six days of life. The participants discussed about the Nursing team organization and care actions. The child did not show any sequelae, as it was monitored by a referral service, where the entire team was trained to treat patients with MSUD.

Chart 1 - Description of the clinical cases used in the second stage of the "Genetics in Pediatrics: Applications for Nursing" extension course, Porto Alegre, 2019

Source: Research data, 2019. 


\section{Fourth Stage - Realistic Simulation}

\begin{tabular}{l|l} 
Scenario Preparation & $\begin{array}{l}\text { The scenario involved a room for the aforementioned appointment, which was conducted } \\
\text { by a participant as nurse, an actress playing the mother of the NB with microcephaly, with } \\
\text { a medium fidelity simulator representing the baby. }\end{array}$ \\
\hline $\begin{array}{l}\text { Briefing (immediate } \\
\text { stage before conducting } \\
\text { the scenario) }\end{array}$ & $\begin{array}{l}\text { The other course students were observers; they received previous instructions regarding } \\
\text { the observation items to improve learning according to the briefing stage, which } \\
\text { composes the realistic simulation method }\end{array}$ \\
\hline $\begin{array}{l}\text { Running (conducting } \\
\text { the scenario) }\end{array}$ & $\begin{array}{l}\text { The clinical case chosen to support the scenario construction is an anxious and worried } \\
\text { mother, who seeks the BHU asking about the current situation of her baby as the father } \\
\text { blames her for microcephaly. According to the mother, there were no complications } \\
\text { during prenatal and she does not understand how, at this moment, the child presents } \\
\text { changes. At that moment, the physician was in a home visit and the appointment was } \\
\text { transferred to the nurse of the team. }\end{array}$ \\
\hline $\begin{array}{l}\text { Debriefing (conclusion } \\
\text { of the method) }\end{array}$ & $\begin{array}{l}\text { At the end of the scenario, all the participants performed the debriefing with their } \\
\text { instructors, according to the debriefing stages pointed out by the INACSL }{ }^{\left({ }^{8}\right)} \text { : description, } \\
\text { analysis, and synthesis. }\end{array}$
\end{tabular}

Chart 2 - Description of the Realistic Simulation stages, fourth stage of the "Genetics in Pediatrics: Applications for Nursing" extension course, Porto Alegre, 2019.

Source: Research data, 2019.

The last stage consisted of a process to assess the course. For that, a form with seven closed questions and one open question was handed in to the participants. The following results were obtained in the closed questions: all the participants think that the course met their expectations and the objectives proposed. The report regarding the conduction of new editions of the course and its indication to some colleague was unanimous, considering that all the participants assessed the instructors' communication skills as great. In relation to the content, $66.7 \%$ of the participants considered it as optimum, while $33.3 \%$ assessed it as good. For the open question about which stage the participant liked the most, the realistic simulation and the outpatient clinic visit were mentioned, as they enabled better understanding of the lessons.

\section{DISCUSSION}

Advances in Genetics enable new opportunities and challenges for the health system and require competences and abilities from the nurses ${ }^{(9)}$. However, the rarity of genetic diseases contributes to the lack of training of these professionals, who acquired little or no knowledge about the theme during undergraduation ${ }^{(2)}$. The efforts to include this content in nurses' training are still widely discussed, although with little success, resulting in nurses with insufficient knowledge and skill in Genetics ${ }^{(10)}$. These research studies are in line with this study, in which the participants reported the limited approach on the theme during training.

The qualification and training of health teams for the diagnosis and management of patients with genetic diseases are essential practices set forth in the RD protocol, as well as access to tests and medications ${ }^{(2)}$. Educational initiatives must be assessed through changes in the practice, as well as in the confidence and knowledge of the professional, seeking to determine if they are effective in making significant changes in the assessment of genetic risk and in the appropriate management of these patients ${ }^{(11)}$. In this context, nurses must understand not only the hereditary patterns of the diseases, but also be aware of signs and symptoms, identify individuals and families at risk, providing necessary guidelines and care actions, as well as referring patients to the reference services ${ }^{(10,12)}$.

Therefore, it becomes essential to reflect about the improvement in the training and professional development of nurses. In view of that, realistic simulation is a very active method used to develop professional abilities and reflections about health, and consists of a systematic, technical, and rational process that helps to achieve learning objectives in training and continuing education ${ }^{(13-14)}$. 
Realistic simulation expands the knowledge and skill of the professionals, increasing self-confidence in the theme developed ${ }^{(15)}$. Therefore, the use of simulation in continuing education about rare disease becomes important to attain the necessary competences for nurses to act as qualified leaders in the care of children with genetic diseases.

Consequently, in view of the diversity of clinical manifestations and the advances in Genetics, it is necessary that nurses provide comprehensive care to children with genetic diseases. It is also recommended to develop leadership skills, which are necessary to implement organizational changes, aiming to improve the Nursing practice, in addition to achieving better health outcomes ${ }^{(5)}$.

\section{$\square$ CONCLUSION}

The objective of the study was contemplated as it described the experience of developing and operating the extension course. Therefore, it stands out as a contribution to the acquisition of competences by nurses, who will be able to work in the clinical practice with more confidence, theoretical grounds and scientific evidence, which enhances the improvement in the care of children with genetic diseases. It is then believed that this extension action provided knowledge and skills to the participating nurses for promoting and disseminating information about rare diseases to society and qualifying the teams under their leadership.

The relevance of this extension lies in the fact that, due to its development method (presentation of clinical cases, practical activities, and realistic simulation), it was possible to provide the participants with interdisciplinary experiences based on integration, support, and cooperation among those involved. This course converges with one of the goals established by the Nursing Now campaign, which aims to strengthen education and develop Nursing professionals, focused on leadership.

As a possible limitation, there is the conduction of the course in the in-person modality, hindering the adherence of more professionals due to working schedules and/or transportation to the course locus. However, the extension activity can be replicated, even in the online remote modality, due to the social distancing in this period of the COVID-19 pandemic. In this case, the practical part can be conducted by discussing clinical cases through online platforms and digital tools. The outpatient follow-up can be transformed into another scenario of realistic simulation and conducted totally online in the tele-simulation format. There is also the possibility to expand the content to other subject matters, such as: main genetic syndromes, phenylketonuria, osteogenesis imperfecta, spinal muscular atrophy, and the nurse's performance in clinical research on Genetics, among others.

Finally, it is important to highlight that the course described has the potential to be included in Nursing undergraduation courses, meeting the current demand of the institutions with extension courses in undergraduation. Thus, nurses will be qualified with knowledge and skills related to Genetics since their training.

\section{REFERENCES}

1. Ministério da Saúde (BR). Secretaria de Atenção à Saúde. Departamento de Atenção Especializada e Temática. Coordenação Geral de Média e Alta Complexidade. Diretrizes para atenção integral às pessoas com doenças raras no Sistema Único de Saúde. Brasília, DF: Ministério da Saúde, 2014 [cited 2020 Apr 20]. Available from: https://portalarquivos2.saude.gov.br/images/pdf/2014/ junho/04/DIRETRIZES-DOENCAS-RARAS.pdf

2. Iriart JAB, Nucci MF, Muniz TP, Viana GB, Aureliano WDA, Gibbon S. From the search for diagnosis to treatment uncertainties: challenges of care for rare genetic diseases in Brazil. Ciênc Saúde Coletiva. 2019;24(10):3637-50. doi: https://doi.org/10.1590/1413-812320182410.01612019

3. World Health Organization (CH). Geneva: WHO; c2020 [cited 2020 Apr 10] IHR Procedures concerning public health emergencies of international concern (PHEIC); [about 1 screen]. Available from: http://www.who.int/ihr/procedures/ pheic/en/

4. Ministério da Saúde (BR). Protocolo de vigilância e resposta a ocorrência de microcefalia e/ou alterações do sistema nervoso central (SNC). Brasilia, DF; 2016 [cited 2020 Apr 20]. Available from: https://portalarquivos.saude.gov.br/images/pdf/2016/marco/24/ Microcefalia-Protocolo-vigil--ncia-resposta-versa02.1.pdf

5. Kennedy A. Wherever in the world you find nurses, you will find leaders. Rev Latino-Am Enfermagem. 2019;27:e3181. doi: https://doi. org/10.1590/1518-8345.0000.3181

6. Couns SWMG, Jacobs C, Phillips J. Mainstreaming genetics and genomics: a systematic review of the barriers and facilitators for nurses and physicians in secondary and tertiary care. Genet Medicine. 2020;22(7):1149-55. doi: https:// doi.org/10.1038/s41436-020-0785-6

7. Mandrell BN, Hines-Dowell $S$, Nishigaki M. Genetics and genomics: precision health in pediatric oncology. In: Hinds $\mathrm{P}$, Liner L, editors. Pediatric Oncology Nursing. Springer: Cham; 2020. p. 235-49. doi: https://doi. org/10.1007/978-3-030-25804-7_13

8. International Nursing Association for Clinical Simulation and Learning. INACSL Standards Committee. INACSL standards of best practice: simulation SM simulation design. Clin Simul Nurs. 2016;12(Suppl):S5-S12. doi: https://doi. org/10.1016/j.ecns.2016.09.005

9. Nissen KK, Mikkelsen TR, Christiansen K. Genetics in the Danish nursing education: a questionnaire study. J Nurs Educ Pract. 2020;10(1):75-84. doi: https://doi.org/10.5430/jnep.v10n1p75

10. Camak DJ. Increasing importance of genetics in nursing. Nurse Educ Today. 2016;44:86-91. doi: https://doi.org/10.1016/j.nedt.2016.05.018

11. Paneque $M$, Turchetti $D$, Jackson L, Lunt $P$, Houwink E, Skirton H. A systematic review of interventions to provide genetics education for primary care. BMC Fam Pract. 2016;17:89. doi: http://doi.org/10.1186/s12875-016-0483-2 
12. Lise F, Feijó AM, Milbrath VM, Schwartz E. Erros inatos do metabolismo do recém-nascido: atualização de enfermagem. Rev Recien. 2019 [cited 2020 Apr 20];9(25):37-42. Available from: https://www.recien.com.br/index.php/ Recien/article/view/278/pdf

13. Fabri R, Mazzo A, Martins J, Fonseca A, Pedersoli C, Miranda F, et al. Development of a theoretical-practical script for clinical simulation. Rev Esc Enferm USP. 2017;51:e03218. doi: https://doi.org/10.1590/s1980-220x2016265103218

\section{- Acknowledgments:}

For the support received from the Dean of Extension Office (Pró-Reitoria de Extensão, PROREXT) of the Federal University of Rio Grande do Sul.

\section{- Authorship contribution:}

Conceptualization: Silvani Herber, Fernanda Araújo

Rodrigues, Alessandra Vaccari.

Data curation: Silvani Herber, Fernanda Araújo

Rodrigues, Alessandra Vaccari.

Formal analysis: Silvani Herber, Fernanda Araújo

Rodrigues, Alessandra Vaccari.

Funding acquisition: There was no funding.

Investigation: Silvani Herber, Alessandra Vaccari.

Methodology: Silvani Herber, Fernanda Araújo

Rodrigues, Alessandra Vaccari.

Project management: Silvani Herber, Alessandra Vaccari. Resources: Alessandra Vaccari.

Writing - Original draft: Silvani Herber, Fernanda Araújo Rodrigues, Alessandra Vaccari.

Writing - Review and editing: Silvani Herber, Fernanda

Araújo Rodrigues, Alessandra Vaccari.

\section{- Corresponding author:}

Silvani Herber

Email: silvanienfherber@yahoo.com.br
14. Uysal N. Improvement of nursing students'learning outcomes through scenariobased skills training. Rev Latino-Am Enfermagem. 2016;24:e2790. doi: https:// doi.org/10.1590/1518-8345.1310.2790

15. Fey MK, Kardong-Edgren SS. State of research on simulation in nursing education programs [editorial]. J Prof Nurs. 2017;33(6):397-8. doi: https://doi. org/10.1016/j.profnurs.2017.10.009

\section{Associate editor:}

Wiliam Wegner 